\title{
Autism in fiction and autobiography
}

\section{Gordon Bates}

\begin{abstract}
SUMMARY
Many memorable characters in Western culture could be viewed as having features of autism or Asperger syndrome. In spite of the familiarity of autistic stereotypes such as Star Trek's Mr Spock, more completely described characters with autism are still unusual. In recent years there has been a growing interest in autism, mirrored by an increase in depictions of autism in popular works of fiction and autobiography. In this article I will outline the issues that have preoccupied writers and the techniques they have used to demonstrate autistic difference. Some writers have illuminated aspects of the autistic triad of social impairment, abnormalities of language and need for sameness. Other writers have opened our eyes to the autistic world view in its strangeness and richness. Still more have started to examine prejudice, disability rights and the implications of an international autism community. As in other areas of mental health, literature can help inform, entertain and question our attitudes and values.
\end{abstract}

\section{DECLARATION OF INTEREST}

None.

Modern Western literature and popular culture are littered with stereotypes of some of the facets of autism and Asperger syndrome, despite their relatively recent description in the scientific literature. Leo Kanner and Hans Asperger made their original separate descriptions of the conditions as recently as the early 1940s (Kanner 1943; Asperger 1944), but many fictional characters with recognisable autism pre-date this.

Literary depictions range from the reserved, emotionless intellectuals typified by Conan Doyle's Sherlock Holmes to the guileless faux naifs whose role in the narrative is to act as a mirror to the social mores or the inequities of the world around them. Although Holmes' reputation for autism may rest more on his cinematic incarnations than the irascible, cocaine-taking bachelor originally described by Conan Doyle, literary examples of the innocents include Melville's Bartleby, in Bartleby, The Scrivener: A Story of Wall Street (1853) and Harper Lee's Boo Radley in To Kill a Mocking Bird (1960). Other aspects of the autistic personality are a rich source of humour in comic writing, from the pompous and pedantic Mr Pooter in George and Weedon Grossmiths' Diary of a Nobody (1892) to the grotesque Ignatius P. Reilly in J. K. Toole's

\section{BOX 1 Characters with explicit autism in fiction}

Christopher Boone in The Curious Incident of the Dog in the Night-Time (Mark Haddon, 2003)

Lou Arrendale in The Speed of Dark (Elizabeth Moon, 2002)

John Cosway in The Minotaur (Barbara Vine, 2005)

Manfred Steiner in Martian Time-Slip (Philip K. Dick, 1964)

Travis in Little Green Man (Simon Armitage, 2001)

Baba in Clear Light of Day (Anita Desai, 1980)

Randall Eberhardt in Family Pictures (Sue Miller 1991)

A Confederacy of Dunces (1980). However, novels containing characters who show the full triad of primary symptoms of autistic disorder, with impairment of language and socialising and a preference for routine, are relatively rare (Box 1).

The recent growth in rates of diagnosis and the explosion of popular interest in autism in general and in Asperger syndrome in particular have led to an increase in more complete and accurate depictions and the flowering of the so-called autie-biography (Box 2). These accounts also mark a change in societal views towards those with autism, who are increasingly seen not in voiceless supporting roles or bit parts but as characters in their own right. There have also been autobiographies that tell the stories of the parents and carers.

BOX 2 Books by people with autism and by carers

Publications by people with autism Emergence: Labelled Autistic and Thinking in Pictures by Temple Grandin (1986)

Nobody Nowhere: The Remarkable Autobiography of an Autistic Girl by Donna Williams (1998)

Freaks, Geeks and Asperger's Syndrome: A User Guide to Adolescence by Luke Jackson (1998)

Martian in the Playground: Understanding the Schoolchild with Asperger's Syndrome by Claire Sainsbury (2000)

Carers' accounts

George and Sam by Charlotte Moore (2005)

Exiting Nirvana: A Daughter's Life with Autism by Clara Claiborne Park (2002)
Gordon Bates is a consultant child and adolescent psychiatrist running an adolescent unit at Huntercombe Hospital, Stafford. He also works for Solihull Care Trust in an out-patient setting and is a senior clinical lecturer with the University of Birmingham, Department of Psychiatry. Dr Bates has longstanding clinical and research interests in neuropsychiatric and neurodevelopmental disorders of childhood.

Correspondence Dr Gordon Bates, Huntercombe Hospital, Ivetsy Bank, Whaton Aston, Stafford ST19 90T, UK. Email: gordon.bates@fshc.co.uk 


\section{BOX 3 From Emergence: Labeled Autistic (Grandin 1986: p. 17)}

I fingered the painful hat, trying to rub away the walls of fabric. Humming tunelessly, I massaged the material over and over. Now the hat lay in my lap like an ugly blue blob. I had to get rid of it. I decided to throw it out the window. Mother wouldn't notice. She was too busy driving. But at a little over three years old I couldn't crank my window down. Now the hat felt hot and prickly on my lap. It lay there waiting like a monster. Impulsively I leaned forward and tossed it out Mother's window.

She yelled. I covered my ears to shut out the hurting sound. She made a grab for the hat. The car swerved. Suddenly we were jolting into the other lane. I leaned back against the seat and enjoyed the jostling. Jean was in the back seat crying. Even today I remember the bushes planted along the highway. I close my eyes and feel again the warm sun streaming through the window, smell the exhaust fumes and see the red tractor-trailer truck come closer and closer.

Mother tried to turn the wheel, but it was too late. I heard the crush of metal and felt a violent jolt as we sideswiped the red tractortrailer truck and suddenly stopped. I yelled, 'Ice.Ice.Ice.' as broken glass showered all over me. I was not scared at all. It was kind of exciting.

In this article, I primarily use extracts from two of the most influential of the recent books to illustrate features of the condition and highlight the novelty and originality of the autism-spectrum world view. My first example is the popular work of fiction, The Curious Incident of the Dog in the Night-Time (Haddon 2003), in which a teenage boy with Asperger syndrome discovers more than he bargains for when he investigates the murder of his neighbour's dog. Temple Grandin's autobiography Emergence: Labeled Autistic (Grandin \& Scariano 1986) is my second example. In addition to a memorable appearance in Oliver Sacks' book $A n$ Anthropologist on Mars (1996), Temple Grandin has written several subsequent books and has lectured widely about her experiences. She has become an expert in animal handling and continues to pursue

BOX 4 From The Curious Incident of the Dog in the Night-Time (Haddon 2003: p. 4)

I pulled the fork out of the dog and lifted him into my arms and hugged him. He was leaking blood from the fork-holes.

I like dogs. You always know what a dog is thinking. It has four moods. Happy, sad, cross and concentrating. Also, dogs are faithful and they do not tell lies because they cannot talk.

I had been hugging the dog for 4 minutes when I heard screaming. I looked up and saw Mrs Shears running towards me from the patio. She was wearing pyjamas and a housecoat. Her toenails were painted bright pink and she had no shoes on.

She was shouting, 'What in fuck's name have you done to my dog?'

I do not like people shouting at me. It makes me scared that they are going to hit a university career. In her book, she describes her constant struggle with social understanding, which leads to her expulsion from mainstream school but her eventual redemption, becoming a university academic. This early text has paved the way for other writers with autism, young and old, to tell their stories.

\section{A different world view}

Writers use many techniques to convey the sense of difference and distance between the 'neurotypical' (mainstream) and autistic world view. Compare the arresting openings of Temple Grandin's book with that of Mark Haddon's. In the first account (Box 3), Grandin describes a 'flashbulb' memory of a car journey taken with her mother and sister when she was 3 years old. She describes her unwillingness to wear a tight-fitting hat and the lengths to which she went to avoid wearing it. In the second (Box 4), we meet our hero Christopher Boone in a similarly striking introduction.

Both books are written in the first person, which forces you to share their autistic world view. They are deliberately written in simple, child-like language, with its associations of innocence and naivety. In the second extract the use of language is stilted: 'leaking blood' for bleeding. In both extracts the emotional response of the narrator is disturbingly out of kilter with our expectations of how children should react to the events that are portrayed. Both writers fail to focus on the distressing experience of the events and describe either no emotional response or a seemingly inappropriate one. The matter-offact tone and the emphasis on irrelevant visual details also alert us to the fact that the narrator is 'unreliable'. We learn at the outset that we will have to reinterpret their perceptions and version of events, as their account is so highly subjective. Mark Haddon makes use of dramatic irony throughout, ensuring through his descriptions that the reader understands more about what is going on than Christopher himself does.

\section{Empathy and social awareness}

Humans are such social creatures that those who do not need company or do not display emotion in culturally sanctioned ways are viewed with suspicion. Although some people with autism are self-absorbed and content with their own company, many with Asperger syndrome are keen for social contact but struggle to mix or to maintain friendships. Problems with empathising appear to be at the core of this. It is a great handicap being unable to infer other people's emotions from their non-verbal communication or the immediate context. 
A scene in The Curious Incident of the Dog in the Night-Time illustrates Christopher's lack of empathy in a particularly poignant manner. In the course of the book, Christopher discovers that his mother left his father for another man, but his father had lied about her death. The extract in Box 5 describes the moment of their reunion.

Another aspect of poor empathy skills is a lack of self-awareness. If you cannot pick up others' cues, you cannot know how you are being perceived. The resulting lack of restraint is an important component of many comedic creations. By no means all such individuals have autism, but I believe that one of my favourite characters does. Ignatius J. Reilly is the antihero of $A$ Confederacy of Dunces (Toole 1980) (Box 6). He is a corpulent, flatulent but highly educated and eloquent unemployed man who lives with his mother. He is arrogant and highly judgemental and critical of others. The story revolves around his attempts to get a job at his mother's insistence.

Seeking first employment is a very traumatic time for most families with autistic children who have grown up. In the novel, it is a device that brings Ignatius into contact with people he cannot understand and detests. The novel does not mock Ignatius, despite his faults; instead the reader sympathises with his plight and his frustration with the idiots around him. This book gets its title from a Jonathan Swift quotation: 'When a true genius appears in the world, you may know him by this sign, that the dunces are in confederacy against him.' In an autistic coincidence, some have speculated that Jonathan Swift himself had Asperger syndrome.

\section{Use of language}

Oddities in the use of language comprise an important part of the triad of primary autistic symptoms. In life, these peculiarities involve both the form and the content of speech. Mutism, neologisms (novel words) and stock phrases are usually associated with intellectual disability. Literal, pedantic and overly inclusive or formal speech is associated more with Asperger syndrome.

There is a range of ways in which these show themselves in life and can be represented in fiction. One of the earliest convincing depictions of adult autism can be found in Herman Melville's short story, Bartleby, The Scrivener (1853). The eponymous, mysterious stranger, who comes to work as a copywriter at a New York law firm, is depicted as a tragic but almost noble figure, who dies as a result of his inflexibility. His behaviour is recognisably autistic, with his social aloofness, limited conversational ability and resistance to

\section{BOX 5 From The Curious Incident of the Dog in the Night-Time (Haddon,} 2003: p. 236)

And she said, 'Why didn't you write to me, Christopher? I wrote you all those letters. I kept thinking something dreadful had happened, or you'd moved away and l'd never find out where you were.'

And I said, 'Father said you were dead.

And she said, 'What?'

And I said, 'He said you went into hospital because you had something wrong with your heart. And then you had a heart attack and died and he kept all the letters in a shirt box in the cupboard in his bedroom and I found them because I was looking for a book I was writing about Wellington being killed and he'd taken it away from me and hidden it in the shirt box.'

And then Mother said, 'Oh my God.'

And then she didn't say anything for a long while. And then she made a loud wailing noise like an animal on a nature programme on television.

And I didn't like her doing this because it was a loud noise, and I said, 'Why are you doing that?

And she didn't say anything for a while, and then she said, 'Oh, Christopher, I'm so sorry.'

And I said, 'It's not your fault.'

And then she said, 'Bastard. The bastard.' And then, after a while, she said, 'Christopher, let me hold your hand. Just for once. Just for me. Will you? I won't hold it hard,' and she held out her hand.

And I said, 'I don't like people holding my hand.

And then she took her hand back and she said, 'No. OK. That's OK.'

change. There are additional details which are persuasive. He has restricted food preferences, eating only ginger-nut biscuits. He even has periods of catatonic immobility, first described in relation to autism by Wing \& Attwood (1987). Bartleby also has poor eye contact: 'He kept his glance fixed on my bust of Cicero, which as I then sat was directly behind me, some six inches above my head' (Melville 1990 reprint: p. 19).

The depiction of Bartleby's language also rings true. His language is restricted and stereotyped. He avoids speaking to his work colleagues, but will speak to his supervisor in a limited fashion. His

\section{B0X 6 From A Confederacy of Dunces (Toole 2006 reprint: p. 1)}

A green hunting cap squeezed the top of the fleshy balloon of a head. The green earflaps, full of large ears and uncut hair and the fine bristles that grew in the ears themselves, stuck out on either side like turn signals indicating two directions at once. Full pursed lips protruded beneath the bushy black moustache and, at their corners, sank into little folds of disapproval and potato chip crumbs. In the shadow under the green visor of the cap Ignatius P. Reilly's supercilious blue eyes looked down upon the other people waiting under the clock at the D. H. Holmes department store, studying the crowd of people for bad taste in dress. Several of the outfits, Ignatius noticed, were new enough and expensive enough to be properly considered offenses against taste and decency. Possession of anything new or expensive only reflected a person's lack of theology and geometry; it could even cast doubts upon one's soul.

Ignatius himself was dressed comfortably and sensibly. The hunting cap prevented head colds. The voluminous tweed trousers were durable and permitted unusually free locomotion. Their pleats and nooks contained pockets of warm stale air that soothed Ignatius. The plaid flannel shirt made a jacket unnecessary while the muffler guarded exposed Reilly's skin between earflap and collar. The outfit was acceptable by any theological and geometric standards, however abstruse, and suggested a rich inner life. 


\section{B0X 7 From The Curious Incident of the Dog in the Night-Time (Haddon, 2003: p. 50)}

So I said, 'Do you know anything about Wellington being killed?'

And she said, 'I heard about it yesterday. Dreadful. Dreadful.'

I said, 'Do you know who killed him?'

And she said, 'No, I don't.'

I replied, 'Somebody must know because the person who killed Wellington knows that they killed Wellington. Unless they were a mad person and didn't know what they were doing. Or unless they had amnesia.'

And she said, 'Well, I suppose you're probably right.'

I said, 'Thank you for helping me with my investigation.'

And she said, 'You're Christopher, aren't you?'

I said, 'Yes I live at number 36.'

And she said, 'We haven't talked before, have we?'

I said, 'No I don't like talking to strangers.

But I'm doing detective work.'

And she said, 'I see you every day, going to school.'

I didn't reply to this.

And she said, 'It's very nice of you to come and say hello.'

I didn't reply to this either because Mrs Alexander was doing what is called chatting where people say things to each other which aren't questions and answers and aren't connected.
Then she said, 'Even if it's only because you're doing detective work.'

And I said, 'Thank you,' again.

And I was about to turn and walk away when she said, 'I have a grandson your age.'

I tried to do chatting by saying, 'My age is

15 years and 3 months and 3 days.'

And she said, 'Well, almost your age.'

Then we said nothing for a little while until she said, 'You don't have a dog, do you?'

And I said, 'No'.

She said, 'You'd probably like a dog, wouldn't you?'

And I said, 'I have a rat.'

And she said, 'A rat?'

And I said, 'He's called Toby.'

And she said, 'Oh'.

And I said, 'Most people don't like rats because they think they carry diseases like bubonic plague. But that's only because they lived in sewers and stowed away on ships coming from foreign countries where there were strange diseases. But rats are very clean. Toby is always washing himself. And you don't have to take him out for walks. I just let him run around my room so that he gets some exercise. And sometimes he sits on my shoulder or hides in my sleeve like it's a burrow. But rats don't live in burrows in nature.' stock phrase is 'I would prefer not to.' He repeats this on 23 occasions in the course of the short story. Even when refusing to do office work he says this phrase in 'a singularly mild, firm voice' so that it is not a challenge. Ironically, this phrase is picked up by his more social co-workers and becomes part of office parlance. Bartleby can be very literal in his understanding of language. After his employer moves to different offices to escape from him, Bartleby remains. When he is asked what he is doing there (in the vacated offices), he replies 'sitting upon the banister'. This is factually accurate but not the answer to the implied, more general question.

In The Curious Incident of the Dog in the Night-Time, there are some well-observed passages of dialogue that illustrate the semantic and pragmatic language problems of those with Asperger syndrome. The semantic impairment is the individual's difficulty in ascertaining meaning from the context when language is ambiguous. The pragmatic problems are related to the practicalities of making conversation, such as conversational repair (knowing how to restart conversation when it becomes derailed).

Christopher starts investigating the death of the dog, like his fictional hero Sherlock Holmes, who in a short story Silver Blaze was also struck by 'the curious incident of the dog in the night-time'. In Box 7 we can read how Christopher starts by interviewing one of his neighbours.

\section{Information overload}

Sometimes personal accounts and fictions can remind doctors of their patients' more pressing concerns, helping to shift their clinical focus. Although not a part of the way autistic disorder is defined, people with autism frequently struggle with the processing of sensory information. They can easily be overwhelmed by the sheer mass of information that our senses perpetually generate, particularly at times of stress. They seem to be unable to filter out the extraneous and peripheral. The reverse of this is also true: most of us see but do not see. It is the role of the novelist to help us to observe again.

Several novelists have attempted to encapsulate in literary form the way we think and experience the world continually. Perhaps the most well known is James Joyce's attempt in Ulysses (1922). However, this forbidding book is a considerable challenge to the casual reader. My own preference to exemplify this approach is Nicholson Baker's The Mezzanine (1988). The 'action' of this novella takes place in a business lunch hour. It is funny and full of digressions about the minutiae of life such as why plastic straws replaced paper straws despite the fact that they float in fizzy drinks, how to overcome public micturition anxiety and why shoelaces break. The text on the page is deliberately close set. There are few paragraph breaks and almost endless footnotes that go on to the next page. The language is clear but formal, with long rambling sentences containing subclause after subclause. Most striking is the very visual way that the world is described. The descriptions are over-inclusive and focus on trade names and seemingly irrelevant details. It has been described as a reflection on the 'information age', but I find it very suggestive of the autistic world view, particularly with the fascinating observations about how things work, from everyday objects to body language (Box 8).

\section{Sensory disturbance}

Many people with autism find particular sounds, smells and textures so intense that they are painful or distressing. Tony Attwood (1998), a leading figure in the advancement of the popular understanding 
BOX 8 From The Mezzanine (Baker, 1990 reprint: p. 30)

\section{'I sign where?'}

'Anywhere. Here's a pen.'

I had already half pulled out my shirt-pocket pen, but not wanting to refuse her offer, I hesitated; at the same time she saw that I already had a pen and with an 'Oh' began to retract hers from the proffering position; meanwhile had decided to accept hers and had let go of the one in my pocket, not registering until it was too late that she had withdrawn her offer; she seeing that I was now beginning to reach for her pen, cancelled her retraction, but meanwhile I, processing her earlier corrective movement, had gone back to reaching for my own pen - so we went through a little foilwork that was like the mutual bobbings you exchange with an oncoming pedestrian, as both of you lurch to indicate whether you are going to pass to the right or left.

of autism, describes an evocative extract from the scientific literature (Cesaroni 1991). When asked why he was reluctant to play in the garden at home, a young boy with autism replied that he hated the 'clack-clack' noise of the wings of butterflies. This is a good example of the usefulness of first-hand accounts of autism in qualitative research but equally a beautifully poetic image.

In Emergence: Labeled Autistic, Temple Grandin describes her own problems with sensory modulation and how specific sounds, smells and textures are experienced as unbearable. By her description of her sensations at Christmas and Thanksgiving she subverts our Western cultural norms of idealised family gatherings (Box 9).

\section{Autism and society}

Some novels have even brought important issues from the culture of autism to a wider audience. In

\section{BOX 9 From Emergence: Labeled Autistic (Grandin 1986: p. 25)}

At those times [Christmas and Thanksgiving] our home bulged with relatives. The clamour of many voices, the different smells - perfume, cigars, damp wool caps or gloves - people moving about at different speeds, going in different directions, the constant noise and confusion, the constant touching were overwhelming. One very, very overweight aunt, who was very generous and caring let me use her professional oil paints. I liked her. Still when she hugged me, I was totally engulfed and I panicked. It was like being suffocated by a mountain of marshmallows. I withdrew because her abundant affection overwhelmed my nervous system.
Asperger chat rooms people debate whether or not autism is an illness, a handicap or a condition. In Elizabeth Moon's science fiction novel The Speed of Dark (2002), the possibility of a cure for autism is considered and the concept of what constitutes normality is questioned. Owing to his phenomenal ability to see patterns in data-sets, the central character, Lou Arrendale, has been head-hunted to work for a prestigious company. Like all his immediate colleagues, he has autism and his skills are known to be related to his condition. Their supervisor ensures that they work in an autismfriendly environment and protects them from the prejudices of other employees. Their work environment includes hanging mobiles, a gym, separate showering and washing facilities and a trampoline to bounce away their stresses. The problems come when the new company executives see these things as an expensive luxury and question the need for preferential treatment. They propose experimental 'normalisation treatment', without understanding that the abilities of these employees and their autism are inextricably linked.

This may sound fanciful but like other disability rights groups, those concerned with autism are keen to argue for the right to life and rightly oppose the possibility of abortion on the grounds of autism. Elizabeth Moon makes no secret of the fact that she has a son with autism and this experience clearly shows in her novel, both in the character of Lou and in her valuing of those with autism. Currently, the argument about whether we should 'cure' autism is hypothetical, but it will only be a matter of time before genetic advances mean that prenatal testing becomes a real possibility. I believe that the autism literature allows us a glimpse into the autistic world, in all its alien glory. We can shrink away from it or relish the multiplicity of viewpoints that it offers.

Both fictional and autobiographical accounts can help us to start to understand the autistic experience and empathise with those affected and their families. They also give us an insight into our own and society's attitudes towards autism. Through the previous examples I have illustrated the evolution of Western society's relationship with the condition. From taking peripheral parts in the narrative, people on the autistic spectrum now command their own storylines. They are revealed as fellow humans, albeit those with a fundamentally different way of understanding the world. Sometimes that way of understanding is shown not just as different but in a positive light. Sometimes the autistic world view is even shown as superior. This represents a massive change in societal attitudes.

\begin{tabular}{llll}
\multicolumn{4}{l}{ MCO answers } \\
1 & 2 & 3 & 4 \\
af & af & at & af \\
bt & bf & bf & bf \\
cf & cf & cf & cf \\
df & dt & df & dt \\
ef & ef & ef & ef
\end{tabular}

ef e 


\section{References}

Armitage S (2001) Little Green Man. Viking.

Asperger H (1944) Die 'Autistischen Psychopathen' im Kindesalter. Archiv für Psychiatrie und Nervenkrankheiten; 117: 76-136.

Attwood T (1998) Asperger's Syndrome: A Guide for Parents and Professionals. Jessica Kingsley.

Baker N (1988) The Mezzanine. Reprinted 1990, Granta Books.

Cesaroni L \& Garber M (1991) Exploring the experience of autism through first hand accounts. Journal of Autism and Developmental Disorders; 21: 303-13.

Desai A (1980) Clear Light of Day. Heinemann.

Dick PK (1964) Martian Time-Slip. Ballantine Books.

Grandin T, Scariano MM (1986) Emergence: Labeled Autistic. Arena Press.

Grandin T (1996) Thinking in Pictures. Vintage Books.

Grossmith G, Grossmith W (1892) The Diary of a Nobody. J. W. Arrowsmith.

Haddon M (2003) The Curious Incident of the Dog in the Night-Time. Jonathan Cape.

Jackson L (1998) Freaks, Geeks and Asperger's Syndrome: A User's Guide to Adolescence. Jessica Kingsley.

Joyce J (1922) Ulysses. Sylvia Beach.
Kanner L (1943) Autistic disturbances of affective contact. The Nervous Child; 2: 217.

Lee H (1960) To Kill a Mocking Bird. Heinemann.

Melville H. (1853) Bartleby, The Scrivener: A Story of Wall Street. Reprinted (1990) as Bartleby and Benito Cereno. Dover Publications.

Miller S (1991) Family Pictures. Penguin.

Moon E (2002) The Speed of Dark. Ballantine Books.

Moore C (2005) George and Sam. Penguin.

Park C (2002) Exiting Nirvana: A Daughter's Life with Autism. Backbay Books.

Sacks 0 (1995) An Anthropologist on Mars. Picador.

Sainsbury C (2000) Martian in the Playground: Understanding the Schoolchild with Asperger's Syndrome. Lucky Duck Publishing.

Toole JK (1980) A Confederacy of Dunces. Reprinted 2006. Penguin Books.

Vine B (2005) The Minotaur. Viking.

Williams D (1998) Nobody Nowhere: The Remarkable Story of an Autistic Girl. Jessica Kingsley.

Wing L, Attwood A (1987) Syndromes of autism and atypical development. In Handbook of Autism and Pervasive Developmental Disorder (eds $\mathrm{D}$ Cohen, A Donnellan). John Wiley \& Sons.

\section{MCO \\ 1 Autism-spectrum disorder rarely presents with: \\ a sensitivity to noise or texture \\ b formal thought disorder \\ c preference for routine and fear of novelty \\ d some form of language disorder \\ e difficulties with mixing with others and empathy skills.}

2 People with autism-spectrum disorder:

a are unable to hold unsupported employment b are unable to write for the general public c universally wish for a 'cure' for autism

$d$ can be good observers of human behaviour

e easily understand other people's intentions and motivations.

\section{It would be difficult to illustrate autism} in literature using:

a the pathetic fallacy

b first-person narrative

c dramatic irony

d excessive attention to visual detail

e naturalistic reproduction of speech patterns.

\author{
4 Abnormalities of language in autism rarely \\ include: \\ a neologisms \\ b stock phrases \\ c literal understanding \\ d verbigeration \\ e overinclusivity.
}

